\title{
SROVNÁNÍ VYBRANÝCH ADSORBENTŮ PRO ODSTRAŇOVÁNÍ KOVŮ Z VODY
}

\section{COMPARISON OF SELECTED ADSORBENTS FOR REMOVAL OF METALS}

\author{
Světlana Moravčíková*, ${ }^{*}$, Renata Biela ${ }^{1}$
}

"moravcikova.s@fce.vutbr.cz

'Ústav vodního hospodářství obcí, Fakulta stavební, Vysoké učení technické v Brně, Žižkova 17, 60200

\begin{abstract}
Abstrakt
Mezi řadu látek, které v současnosti znečišt’ují zdroje pitné vody patř́i také různé kovy a jejich sloučeniny. Za účelem porovnání vybraných sorpčních materiálů pro odstranění kovů z vody byl proveden laboratorní experiment. K experimentálnímu porovnání byly vyžity filtrační kolony, naplněné vybranými sorpčními materiály GEH a Bayoxide E33. Sorpcí byly z vody odstraňovány kovy arsen, nikl a olovo. Na základě několika kritérií byl jako vhodnější materiál vyhodnocen materiál Bayoxide E33.
\end{abstract}

\section{Klíčová slova}

Sorpční materiály, kovy, polutanty, pitná voda

\begin{abstract}
Various metals and their compounds are among the number of substances that currently pollute drinking water sources. A laboratory experiment was performed to compare selected sorption materials for removing metals from water. Filter columns filled with selected sorption materials GEH and Bayoxide E33 were used for experimental comparison. The metals arsenic, nickel and lead were removed from the water by sorption. Based on several criteria, Bayoxide E33 was evaluated as a more suitable material.
\end{abstract}

\section{Key words}

Sorption materials, metals, pollutants, drinking water

\section{1 ÚVOD}

V současnosti se ve zdrojích pitné vody objevuje množství znečišt’ujících látek, mezi které řadíme i kovy a jejich sloučeniny, škodící nejen člověku, ale také ostatním živočichům a rostlinám. Dále mohou negativně ovlivnit také zemědělství či průmyslové závody, které mají často přísnější požadavky na jakost vody.

Zvyšující se úroveň urbanizace a potřeba vody v oblastech průmyslové činnosti, která s ní souvisí, výrazně přispívají k problému výskytu kovů v podzemních zdrojích vody. V malých množstvích jsou určité kovy esenciální pro zdraví člověka, ve velkých množstvích však mohou způsobovat akutní či chronickou toxicitu [1].

Kovy jako jsou vápník, hořčík, draslík a sodík by měly být v těle př́itomny v určitém množství, aby udržely např. acidobazickou rovnováhu. Železo, mangan, měd', kobalt, molybden či zinek je pak zapotřebí udržovat v těle v nízkých koncentracích. V prŕípadě nedostatku, př́ípadně naopak vysokých koncentrací těchto kovů, může docházet ke zdravotním komplikacím. Pití vody s obsahem toxických kovů jako je arsen, kadmium, chrom, olovo, rtut' a nikl může vést k velmi závažným zdravotním komplikacím, mnohdy končícím smrtí [1].

Většina těžkých kovů se dostává do životního prostředí z průmyslové činnosti, přičemž dochází $\mathrm{k}$ průsaku do podzemních vod, které jsou následně užívány jako zdroje pitné vody. Toxické kovy představují nejvyšší formu perzistentních polutantů znečišt'ujících životní prostředí, přičemž jsou chemicky a biologicky nezničitelné [1]. 


\section{POPIS SOUČASNÉHO STAVU}

V roce 2020 byla provedená statická zkouška v kádinkách, při níž byly sledovány koncentrace toxických kovů ve vodě při sorpci na filtrační materiály GEH a Bayoxide E33. V návaznosti na tento experiment byla o rok později se stejnými materiály provedena dynamická zkouška.

\section{Kovy}

Téměř všechny kovy jsou ve vodách obsaženy alespoň ve stopových množstvích. K obohacení vody dochází stykem s horninami a půdou. To se týká především makrokomponent ( $\mathrm{Ca}, \mathrm{Mg}, \mathrm{Na}, \mathrm{K})$, avšak v okolí rudných nalezišt' může dojít také k obohacení vody vysokým množstvím toxických kovů [2].

V pitné vodě je limitováno 18 kovů a polokovů, jejich obsah patří i mezi ukazatele př́ípustného obsahu látek v povrchových vodách. Negativní vliv vyšších koncentrací některých kovů nemusí spočívat v jejich toxicitě, ale především v ovlivnění organoleptických a technických vlastností vody [2].

Mezi nejvýraznější ukazatele znečištění podzemních vod v roce 2019 patřily tyto kovy: baryum, mangan, arsen a kobalt [3], v roce 2017 byl mezi nimi také nikl [4].

\section{Adsorpce}

Adsorpce je v praxi hojně využívána k odstranění látek z tekutých fází. Lze ji pozorovat také jako přirozený proces v různých složkách životního prostředí. Při úpravě vody se adsorpce prokázala jako účinný proces při odstraňování mnoha rozpuštěných látek. Molekuly nebo ionty jsou odstraněny z vodného roztoku adsorpcí na pevné povrchy [5].

Ve vodárenství je adsorpce běžně používanou metodou pro úpravu pitné vody. Slouží k eliminaci nežádoucích látek, které způsobují změnu senzorických vlastností vody a vedlejších látek vznikajících při dezinfekci vody. Při adsorpčních procesech mohou být použity různé sorpční materiály, které se dělí do několika skupin podle účelu odstraňování látek z vody. Pro odstraňování kovů patří v současnosti mezi nejpoužívanější adsorbenty granulované filtrační materiály na bázi oxidu a hydroxidu železa, kterými jsou také materiály GEH a Bayoxide E33 [6].

\section{Použité sorpční materiály}

GEH je sorbent založený na bázi granulovaného hydroxidu železa. Je vhodný k hospodárnému a efektivnímu odstranění arsenu a antimonu z vody. Adsorpční kapacita materiálu závisí na provozních podmínkách [7].

Bayoxide E33 je suchý krystalický granulovaný sorpční materiál na bázi oxidů železa. Byl vyvinut společností Severn Trent ve spolupráci se společností Bayer AG. Materiál byl navržen k odstraňování arsenu, jeho výhodou je, že společně s oběma formami arsenu ( $\left.\mathrm{As}^{\mathrm{III}} \mathrm{a} \mathrm{As}^{\mathrm{V}}\right)$ odstraňuje také železo a mangan [8].

Tab. 1 Přehled vlastností sorpčních materiálů [7].

\begin{tabular}{ccc}
\hline Parametr/Jednotka & Bayoxide E33 & GEH \\
\hline Velikost částic $/ \mathrm{mm}$ & $0,5-2,0$ & $0,2-2,0$ \\
Objemová hmotnost $/ \mathrm{g} \cdot \mathrm{cm}^{-3}$ & $0,4-0,6$ & 1,25 \\
Specifický povrch $/ \mathrm{m}^{2} \cdot \mathrm{g}^{-1}$ & $120-200$ & $250-300$ \\
Barva & jantarová & tmavě hnědá až černá \\
\hline
\end{tabular}

\section{METODIKA}

Filtrace probíhala v kolonách s vnitřním průměrem $4,4 \mathrm{~cm}$. Na dně těchto kolon byla vytvořena drenážní vrstva zabraňující úniku sorpčních materiálů při filtraci. Spodní část drenážní vrstvy tvořily kameny o velikosti 1 až 2 $\mathrm{cm}$, na které navazovala vrstva skleněných kuliček o průměru $4 \mathrm{~mm}$. Horní část drenážní vrstvy tvořily $2 \mathrm{~mm}$ skleněné kuličky. Nad drenážní vrstvu byl poté nasypán filtrační materiál. Výška této vrstvy byla zvolena na základě doporučení výrobce. Minimální výška pro GEH byla $0,8 \mathrm{~m}$, tato výška byla použita pro oba materiály. Materiály bylo před experimentem proprat. Praní probíhalo zdola nahoru do doby, kdy z kolony začala vytékat čistá voda. Prací voda byla svedena do kanalizace. 
Dále bylo nutné připravit modelovou vodu. Modelová voda vznikla přidáním sledovaných kovů - arsenu, niklu a olova. Po přidání kovů do vodovodní vody bylo nutné důkladné promíchání, aby došlo k disperzi kovů v objemu vody.

Do barelu s vodou byla vložena sací hadice čerpadla. Voda byla čerpána přes průtokoměr do jednotlivých kolon. Množství protékající vody bylo regulováno na průtokoměru, s maximálním průtokem definovaným na 20 l/h. Vzorky filtrované vody byly poté odebírány z výstupů spodní kolony v předem zvolených časech - 1, 2, 4 a 6 minut od okamžiku kdy voda začala vytékat z kolony. U odebraných vzorků bylo během experimentu př́mo v laboratoři měřeno $\mathrm{pH}$, teplota a zákal. Po provedení experimentu byly vzorky odvezeny na brněnskou pobočku Zdravotního ústavu se sídlem v Ostravě ke stanovení koncentrací sledovaných kovů.

\section{VÝSLEDKY}

V Tab. 1 a Tab. 2 jsou zaznamenány naměřené veličiny v jednotlivých vzorcích a stanovené hodnoty koncentrací jednotlivých kovů.

Tab. 2 Výsledky adsorpce na materiálu GEH.

\begin{tabular}{ccccccc}
\hline $\begin{array}{c}\check{\mathbf{c a s}} \\
{[\mathbf{m i n}]}\end{array}$ & $\begin{array}{c}\mathbf{p H} \\
{[-]}\end{array}$ & $\begin{array}{c}\text { teplota } \\
{\left[{ }^{\circ} \mathbf{C}\right]}\end{array}$ & $\begin{array}{c}\text { zákal } \\
{[\mathbf{Z F}]}\end{array}$ & $\begin{array}{c}\mathbf{c}_{\mathbf{A s}} \\
{[\boldsymbol{\mu g} / \mathbf{l}]}\end{array}$ & $\begin{array}{c}\mathbf{c}_{\mathbf{N i}} \\
{[\boldsymbol{\mu g} / \mathbf{l}]}\end{array}$ & $\begin{array}{c}\mathbf{c} \mathbf{P b} \\
{[\boldsymbol{\mu g} / \mathbf{l}]}\end{array}$ \\
\hline 0 & 7,08 & 17,7 & 1,47 & 24,0 & 45,8 & 29,6 \\
1 & 6,58 & 20,5 & 1,34 & $<1,0$ & 14,1 & $<1,0$ \\
2 & 6,45 & 20,8 & 0,64 & $<1,0$ & 10,3 & $<1,0$ \\
4 & 6,02 & 21,5 & 0,60 & $<1,0$ & 7,3 & $<1,0$ \\
6 & 5,81 & 21,0 & 0,37 & $<1,0$ & 6,2 & $<1,0$ \\
\hline
\end{tabular}

Tab. 3 Výsledky adsorpce na materiálu Bayoxide E33.

\begin{tabular}{|c|c|c|c|c|c|c|}
\hline \multirow[b]{2}{*}{$\begin{array}{c}\text { čas } \\
{[\text { min] }}\end{array}$} & \multicolumn{6}{|c|}{ Bayoxide E33 } \\
\hline & $\begin{array}{c}\mathbf{p H} \\
{[-]}\end{array}$ & $\begin{array}{c}\text { teplota } \\
{\left[{ }^{\circ} \mathrm{C}\right]}\end{array}$ & $\begin{array}{c}\text { zákal } \\
{[\mathrm{ZF}]}\end{array}$ & $\begin{array}{c}\mathrm{c}_{\mathrm{As}} \\
{[\mu \mathrm{g} / \mathrm{l}]}\end{array}$ & $\begin{array}{c}\mathbf{c}_{\mathrm{Ni}} \\
{[\mu \mathrm{g} / \mathrm{l}]}\end{array}$ & $\begin{array}{c}\mathbf{c}_{\mathrm{Pb}} \\
{[\boldsymbol{\mu g} / \mathrm{l}]}\end{array}$ \\
\hline 0 & 7,08 & 17,7 & 1,47 & 24,0 & 45,8 & 29,6 \\
\hline 1 & 7,02 & 20,2 & 1,17 & 1,75 & $<2,0$ & 5,5 \\
\hline 2 & 7,05 & 21,6 & 0,71 & 1,30 & $<2,0$ & 4,1 \\
\hline 4 & 7,08 & 21,6 & 0,59 & 1,0 & $<2,0$ & 3,3 \\
\hline 6 & 7,05 & 21,0 & 0,47 & $<1,0$ & $<2,0$ & 2,6 \\
\hline
\end{tabular}

Hodnoty koncentrací kovů byly následně zpracovány do grafů (Obr.1, Obr.2 a Obr.3), sloužících k přehlednému porovnání výsledků materiálů GEH a Bayoxide E33 a také k posouzení, zda vzorky splňují limity kovů dané pro pitnou vodu. V grafech jsou zaznačeny limitní koncentrace kovů dané Vyhláškou 252/2004 Sb., které jsou následující: pro arsen a olovo $10 \mu \mathrm{g} / 1$, pro nikl $20 \mu \mathrm{g} / 1$ [9]. 


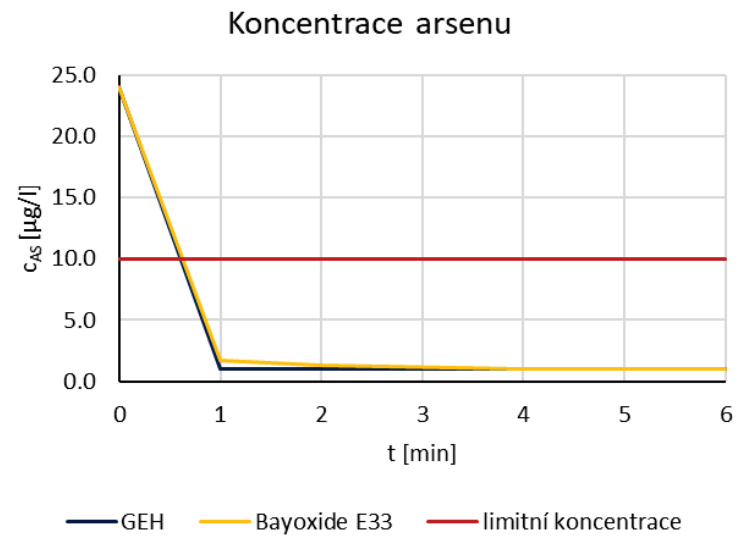

Obr. 1 Výsledný graf průběhu koncentrace arsenu.

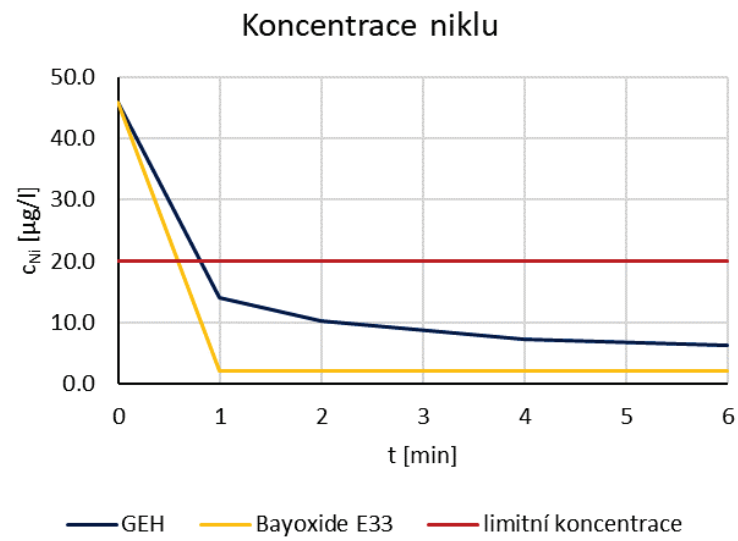

Obr. 2 Výsledný graf průběhu koncentrace niklu.

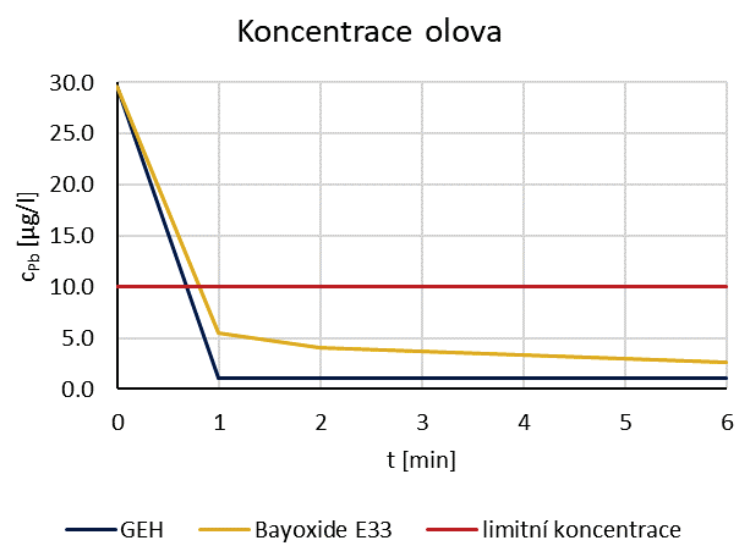

Obr. 3 Výsledný graf průběhu koncentrace olova. 


\section{DISKUZE}

Zaměříme-li se nejprve na koncentrace jednotlivých kovů, u všech sledovaných kovů došlo již po 1 minutě k odstranění hluboko pod limitní hodnoty stanovené vyhláškou. Materiál GEH v př́ípadě arsenu již po 1 minutě snížil koncentraci tohoto kovu pod limit detekce a dosáhl tak mírně lepších výsledků než Bayoxide E33, který koncentraci snížil pod limit detekce až po 6 minutách. Při odstraňování niklu, pak naopak dosáhl znatelně lepších výsledků materiál Bayoxide E33, který už po 1 minutě dosáhl koncentrace tohoto kovu pod limitem detekce, materiál GEH pak zanechal koncentrace po celou dobu nad tímto limitem. V případě olova pak opět dosáhl lepších výsledků materiál GEH, s koncentracemi olova po celou dobu pokusu pod limitem detekce. Avšak i Bayoxide E33 snízil koncentrace kovu na hodnoty velmi blízké tomuto limitu.

Pouze na základě koncentrací kovů by se jevil jako lepší materiál GEH, avšak podíváme-li se na další měřené hodnoty, konkrétně $\mathrm{pH}$, je nutné tuto úvahu přehodnotit. V př́padě materiálu GEH totiž $\mathrm{pH}$ během experimentu kleslo až na hodnotu 5,81, cože je mimo limit pH pitné vody, který je 6,5-9,5.

\section{ZÁVĚR}

Pití vody s obsahem toxických kovů jako je arsen, olovo a nikl může vést k závažným zdravotním komplikacím, proto je důležité, aby tyto kovy z pitné vody odstraňovat. V rámci provedeného experimentu byla vyzkoušena schopnost vybraných sorpčních materiálů odstranit tyto vybrané toxické kovy z vody.

Při zkoušce provedené v laboratoři Ústavu vodního hospodářství obcí Fakulty stavební VUT v Brně dosáhl mírně lepších výsledků při odstraňování kovů materiál GEH. Lze však konstatovat, že oba zvolené materiály byly schopné odstranit vybrané kovy tak, aby byly splněny limity dané Vyhláškou 252/2004 Sb. V případě GEHu pak navíc došlo ke snížení pH mimo limitní hodnoty pro pitnou vodu, což by znamenalo nutnost další úpravy vody za účelem zvýšení pH. Na základě této skutečnosti se tak jako vhodnější materiál jeví Bayoxide E33.

V rámci dalšího výzkumu by bylo vhodné zaměřit se také na problematiku snížení pH vody materiálem GEH, zjistit, čím je zapříčiněno a zda je možné mu nějakým způsobem předcházet.

\section{Poděkování}

Př́spěvek byl zpracován v rámci řešení grantového projektu specifického vysokoškolského výzkumu na VUT v Brně s názvem “Řešení vybraných problémů ve vodním hospodářství obcí” (FAST-J-21-7477).

\section{Použité zdroje}

[1] FERRANTE, Margherita, Gea OLIVERI CONTI, Zorica RASIC-MILUTINOVIC a Dragana JOVANOVIC. Health effects of metals and related substances in drinking water. London: IWA Publishing, 2014. Metals and related subatances in drinking water series. ISBN 978-1-78040-598-8.

[2] PITTER, Pavel. Hydrochemie. 5. vydání. Praha: VŠCHT Praha, 2015. ISBN 978-80-7080-928-0.

[3] Zpráva o stavu vodního hospodářství České republiky v roce 2019 [online]. Praha: Ministerstvo zemědělství, 2020 [cit. 2021-11-12]. ISBN 978-80-7434-570-8. Dostupné z: https://eagri.cz/public/web/file/669424/Modra_zprava_2019_web.pdf

[4] Zpráva o stavu vodního hospodářství České republiky v roce $20 \overline{1} 7$ [online]. Praha: Ministerstvo zemědělství, 2018 [cit. 2021-11-12]. ISBN 978-80-7434-463-3. Dostupné z: http://eagri.cz/public/web/file/607186/Modra_zprava_2017_WEB_18.pdf

[5] WORCH, Eckhard. Adsorption Technology in Water Treatment: Fundamentals, Processes, and Modeling. Drážd’any: de Gruyter, 2012. ISBN 978-3-11-024023-8.

[6] MARKO, Ivana, Danka BARLOKOVÁ a Ján ILAVSKÝ. Použitie vybraných sorpčných materiálov pri odstran̆ovaní bromičnanov z vody. TZB-info [online]. 21. 5. 2018 [cit. 2021-11-22]. Dostupné z: https://1url.cz/XKUP9

[7] BIELA, Renata and Lucie ŠOPÍKOVÁ. Efficiency of sorption materials on the removal of lead from water. Applied Ecology and Environmental Research [online]. 2017, 15(3), 10 [cit. 2021-11-27]. ISSN 1785 0037. Dostupné z: http://aloki.hu/indvol15_3.htm

[8] ILAVSKÝ, Ján a Danka BARLOKOVÁ. Odstraňovanie niklu z vody sorpčnými materiálmi. TZBinfo [online]. 23. 5. 2011 [cit. 2021-11-27 ]. Dostupné z: https://voda.tzb-info.cz/vlastnosti-a-zdrojevody/7482-odstranovanie-niklu-z-vody-sorpcnymi-materialmi

[9] Vyhláška č. 252/2004 Sb., vyhláška, kterou se stanoví hygienické požadavky na pitnou a teplou vodu a četnost a rozsah kontroly pitné vody. 